\title{
Effects of Methyl Jasmonate and Salicylic Acid on Alkaloid Production from in vitro Culture of Stemona sp.
}

\author{
Natthiya Chaichana and Srisulak Dheeranupattana
}

\begin{abstract}
Plant tissue culture technique combined with elicitors is required to produce plant secondary metabolites. The results showed that both elicitors (methyl jasmonate and salicylic acid) could enhance the production of Stemona alkaloids in the Stemona sp. culture. Among these elicitors, salicylic acid was found to be the most effective elicitor. The plantlet which was elicited with $100 \mu \mathrm{M}$ salicylic acid for 1 week showed an increase of $1^{\prime}, 2^{\prime}$-didehydrostemo-foline and stemofoline production at $\mathbf{1 . 6 9}$ fold and $\mathbf{1 . 6 1}$ fold higher than the control, respectively.
\end{abstract}

Index Terms-1',2'-didehydrostemofoline, stemofoline, methyl jasmonate, salicylic acid.

\section{INTRODUCTION}

Stemona alkaloids are valuable secondary metabolites produced from Stemona spp. The pure alkaloids and extracts derived from the leaves and roots of Stemona species have been shown to have insect toxicity [1], as well as antioxidant [2] and antitussive activities [3]. Many Stemona alkaloids derived from Stemona species in Thailand have been reported, such as stemocurtisine, stemocurtisinol, oxyprotostemonine and stemokerrin [4]. An unidentified Stemona sp. was collected from Mae Moh District, Lampang, Thailand (this voucher specimen was deposited at the Herbarium (number 25375) of the Department of Biology, Chiang Mai University) from which the isolation of 1',2'-didehydrostemofoline has been reported [5]. It has been shown that 1 ',2'-didehydrostemofoline, when compared to the other Stemona alkaloids, has the highest inhibitory activity against acetylcholinesterase. Thus indicating this compound as a potential therapeutic agent in the treatment of the initial symptoms of Alzheimer's disease [6]. Stemofoline, another Stemona alkaloid found in Stemona sp., also has inhibitory activity against acetylcholinesterase [7]. Further, stemofoline was able to significantly increase the sensitivity of the anticancer drugs, vinblastine, paclitaxel and doxorubicin, to drug resistant cancer cells [8]. For these reasons, these valuable Stemona alkaloids are of interest in the applications of plant tissue culture techniques because alkaloid production from plants grown in nature has not always been considered reliable. Plant tissue culture techniques employing elicitors has been widely used to enhance the production of secondary

Manuscript received April 18, 2012; revised May 30, 2012. This work was supported in part by the Human Resource Development in Science Project (Science Achievement Scholarship of Thailand, SAST), Thailand and the Graduate School, Chiang Mai University, Chiang Mai, Thailand.

N. Chaichana and S. Dheeranupattana are with Department of Biology, Chiang Mai University, Chiang Mai 50200, Thailand (e-mail: nat_too@hotmail.com). metabolites.

Elicitors are chemicals or biofactors derived from various sources that can induce physiological changes of the target living organism. In a broad sense, elicitors for a plant refer to chemicals from various sources that can trigger physiological and morphological responses and phytoalexin accumulation. It is well known that treatment of plants with elicitors, or any attack by incompatible pathogens, causes an array of defense reactions, including the accumulation of a range of plant defensive secondary metabolites, such as phytoalexins in intact plants or in cell cultures [9]. Elicitors can be abiotic or biotic and act individually or in combination to turn on the biosynthesis of molecules that may only be produced in small amounts or may even produce new compounds [10]. Biotic elicitors such as methyl jasmonate (MJ) and salicylic acid (SA) are used in combination with the culture for the highest level of production. For example, MJ was found to enhance the taxol productivity of Taxus cuspidata suspension cultures [11]. This study proposes to investigate the effects of elicitors on alkaloid production from Stemona $\mathrm{sp}$.

\section{EXPERIMENTAL SECTION}

\section{A. Plant Material}

Stemona sp. was collected from Mae Moh District, Lampang, Thailand. Shoot tips and axiliary buds were surface sterilized with $15 \%$ clorox solution for 20 minutes followed by being washed three times with sterilized distilled water. After sterilization, shoot tips and auxiliary buds were cultured on MS [12] agar medium supplemented with $3 \mathrm{mg} / \mathrm{L}$ benzyladenine for multiple shoot induction. For root induction, single shoots were transferred to half-MS medium supplemented with $2 \mathrm{mg} / \mathrm{L}$ indolebutyric acid [13]. The cultures were placed in a growth room at $25 \pm 2{ }^{\circ} \mathrm{C}$ under a 16 $\mathrm{h}$ per day photoperiod.

\section{B. Feeding Elicitors}

Eight-week-old in vitro Stemona plantlets were cultured in liquid MS medium supplemented with various concentrations of MJ or SA for one and two weeks at concentrations of 0.1 , $0.3,0.5$ and $1.0 \mathrm{mM}$. The control treatment was cultured in liquid MS medium without any elicitor being added. MJ solution was purchased from Aldrich and filtered through a $0.2 \mu \mathrm{m}$ syringe filter (Filtrex syringe membrane filtration). SA was dissolved in distilled water. All culture experiments were performed in triplicate. Roots from all treatments, as well as the cultured medium, were extracted and analyzed for Stemona alkaloid production. The total Stemona alkaloid production was expressed as the sum of the amount of alkaloid in the root and the medium. 


\section{Stemona Alkaloids Extraction and Analysis}

Dry roots of Stemona sp. were ground and extracted three times with methanol (Merck, HPLC grade, Germany). The solution was filtered and evaporated to give a crude extract, which was extracted again with dichloromethane (DCM) (Merck, HPLC grade Germany). The crude DCM extract was dissolved and filtered with $0.45 \mu \mathrm{M}$ membrane filter. Finally, Stemona alkaloids were quantified by HPLC (Agilent 1200 series, Palo Atto, CA, USA). Data acquisition and analysis were performed using the Agilent chemstation software. An Inertsil C18 ODS-3 $5 \mu \mathrm{m}$ particle size, $4.6 \times 150 \mathrm{~mm}$ column (GL sciences Inc., Japan) was used. A mixture of methanol and water was used as the mobile phase under gradient elution conditions with a flow rate of $0.5 \mathrm{~mL} / \mathrm{min}$. The gradient conditions are shown in Table I. Detection of compounds was made at $297 \mathrm{~nm}$. A $20 \mu \mathrm{L}$ of the sample was injected into the chromatography system. The analysis was achieved within 27 minutes. Stemona alkaloids were identified after comparison of the retention times of the standards. The retention times of the 1',2'-didehydrostemofoline and stemofoline standards were 11.5 and 18.2 minutes, respectively. Quantification was then achieved by comparing the areas of the corresponding peaks of the standard curves. The standard curves were prepared in the concentration range of $25-1000 \mathrm{mg} / \mathrm{L}$.

\section{Research location}

This research was studied at Plant Tissue Culture Laboratory, Department of Biology, Faculty of Science, Chiang Mai University, Chiang Mai, Thailand.

\section{E. Statistical Analysis}

Statistical significance was determined by analysis of variance (ANOVA) with adjustments for multiple comparisons with Turkey's test. Differences referred to as significant had a P-value of less than 0.05. Data were expressed as the average of three separate experiments.

TABLE I: THE HPLC GRADIENT FLOW CONDITIONS FOR STEMONA ALKALOID SEPARATION.

\begin{tabular}{llll}
\hline $\begin{array}{l}\text { Time } \\
(\mathrm{min})\end{array}$ & Methanol $(\%)$ & Water $(\%)$ & $\begin{array}{l}\text { Flow rate } \\
(\mathrm{mL} / \mathrm{min})\end{array}$ \\
\hline 7 & 70 & 30 & 0.5 \\
7.5 & 10 & 90 & 0.5 \\
12 & 10 & 90 & 0.5 \\
13 & 70 & 30 & 0.5 \\
20 & 70 & 30 & 0.5 \\
\hline
\end{tabular}

\section{RESULTS AND DISCUSSION}

$\mathrm{MJ}$ and its relatives from the oxylipin family originate from lipid-derived compounds. They are involved in several plant processes, such as growth and development [14]. After treatment with various concentrations of MJ, the root growth of the cultures during 1 - and 2-week periods are shown in Figure 1 (a). It was found that the root growth decreased when compared with the control culture. In previous reports, MJ also inhibited the root growth in adventitious root cultures of Scopolia parviflora [15]. For Stemona alkaloids biosynthesis, the total alkaloid production of MJ treatments is shown in Figure 1 (b-c) and Table II (a-b). The experiment shows that
$1.0 \mathrm{mM} \mathrm{MJ}$ with a 1-week culture period resulted in the highest production of $1^{\prime}, 2^{\prime}$-didehydrostemofoline and stemofoline with 1.16 fold and 1.42 when compared with the control, respectively. Similar results showed that tropane alkaloids were induced by $\mathrm{MJ}$ in jimsonweed (Datura stramonium L.) and these results also indicated that MJ enhanced PMT (putrescine $N$-methyltransferase) activity and key alkaloid biosynthetic enzymes, due to the increase of mRNA of PMT [16]. In addition, MJ was shown to induce the accumulation of secondary metabolites by turning on the transcription of several genes involved in their biosynthesis [17]. The Stemona alkaloid content secreted into the medium is shown in Table II (a-b). One week old cultures treated with MJ gave the secretion of stemofoline, while $1^{\prime}, 2^{\prime}$-didehydrostemofoline was not secreted into the medium. It seems to be similar to the secretion and accumulation of terpene indole alkaloids in the hairy roots of Catharanthus roseus treated with MJ. The terpene indole alkaloid content accumulated in the roots and it was also secreted into the medium [18]. Moreover, the exogenous application of MJ also stimulates the biosynthesis of alkaloids in many plants, such as Eschscholtzia californica [19] and Atropa baetica [20].

SA is one of numerous phenolic compounds, defined as compounds containing an aromatic ring with a hydroxyl group or its derivative, found in plants. Exogenously supplied SA was shown to affect a large variety of processes in plants, including stomatal closure, seed germination, fruit yield and glycolysis [21]. To investigate the effect of SA on root growth and the production of Stemona alkaloids, we employed the same method used for MJ. Figure 2 (a) shows the effect of SA on root growth. SA slightly decreased the root growth in many concentrations and especially at $1.0 \mathrm{mM}$ concentration. In general, SA elicitation has a negative effect on growth. In an earlier study, it was reported that SA treatment also slightly inhibited the growth of Salvia miltiorrhiza cell cultures [22]. In addition, it was found that increasing the SA concentrations in the media strongly suppressed the growth of Rubia cordifolia callus cultures [23]. The total Stemona alkaloid accumulation is shown in Figure 2 (b-c) and Table III (a-b). It was found that Stemona alkaloids increased after being cultured for 1 week, however the production after a 2-week culture period with decreased. $0.1 \mathrm{mM}$ SA resulted in the highest level of 1',2'-didehydrostemofoline and stemofoline production at 1.69 fold and 1.61 fold respectively, when compared with the control. Similarly, in the results found in the alkaloid accumulation of suspension-cultured Dendrobium huoshanense, it was revealed that $0.1 \mathrm{mM} \mathrm{SA}$ could enhance the accumulation of alkaloid 1.6 fold when compared with the control [24]. Moreover, SA at a 1-week culture period was appropriate for producing the tropane alkaloid content of Atropa belladonna root cultures. This research also studied alkaloid released into the medium. The result revealed that $\mathrm{SA}$ stimulated the release of tropane alkaloid from the roots into the medium by up to $90 \%$ after 1 week [25]. For this experiment, SA also resulted in the stimulation of stemofoline into the medium (Table III (b)). To support the result, the effect of SA on the tropane alkaloids scopolamine and hyoscyamine in hairy root cultures of Brugmansia candida was investigated and it was found that all concentrations of SA treatment released both the alkaloids 
into the media [26]. In addition, SA also forced the release of the other Stemona alkaloids into the medium [27]. These positive results are probably associated with SA emerging as a key-signaling component involved in the signal transduction pathways of plant defense mechanisms [28].

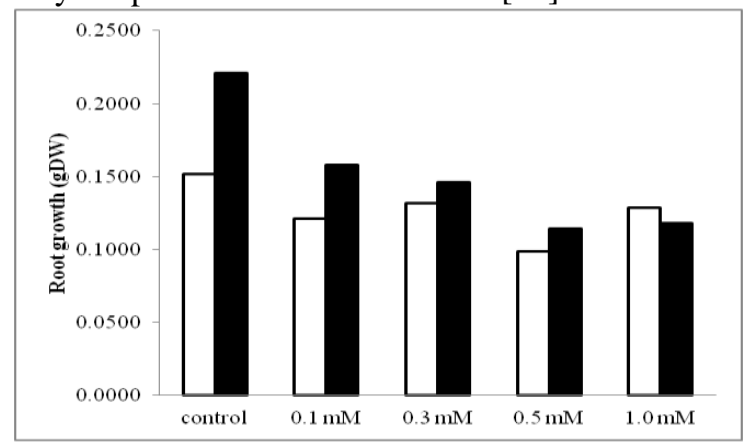

(a)

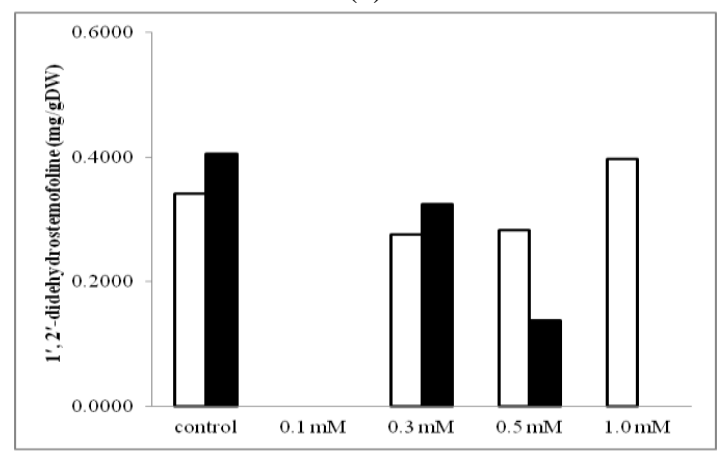

(b)

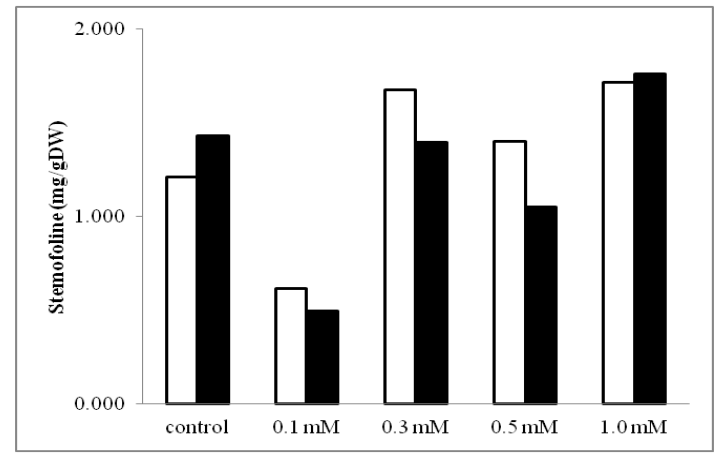

(c)

Fig. 1. The effects of various concentrations of methyl jasmonate on root growth (a), total alkaloid production of $1^{\prime}, 2^{\prime}$-didehydrostemofoline (b) and total alkaloid production of stemofoline (c). The data show the mean of the triplicates. (The light bar and the dark bar represent one week and two-week culture periods, respectively.)

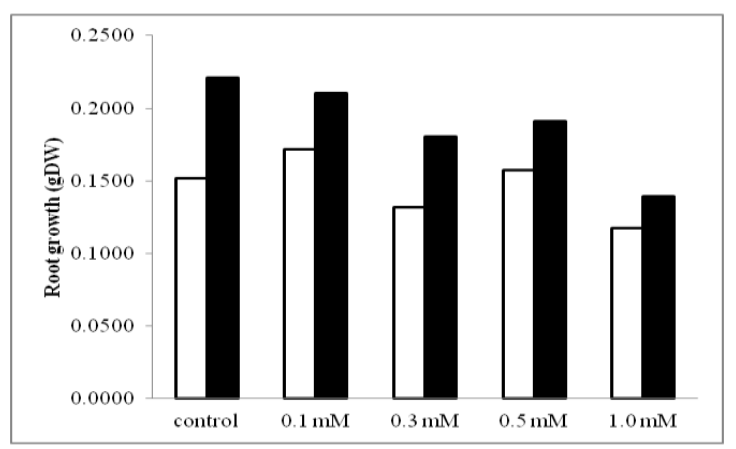

(a)

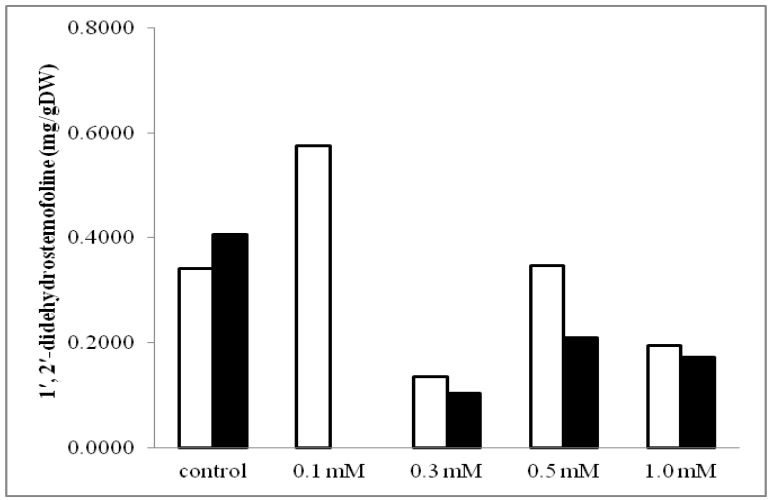

(b)

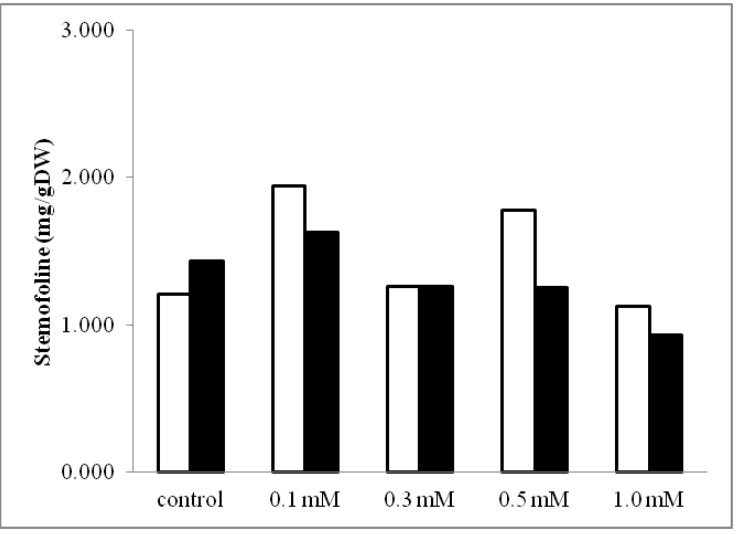

(c)

Fig. 2. The effects of various concentrations of salicylic acid on root growth (a), total alkaloid production of 1',2'-didehydrostemofoline (b) and total alkaloid production of stemofoline (c). The data show the mean of the triplicates. (The light bar and the dark bar represent one week and two-week culture periods, respectively.)

TABLE II: THE EFFECTS OF VARIOUS CONCENTRATIONS OF METHYL JASMONATE ON 1',2'-DidEHYDROSTEMOFOLINE (A) AND STEMOFOLINE (B) PRODUCTION.

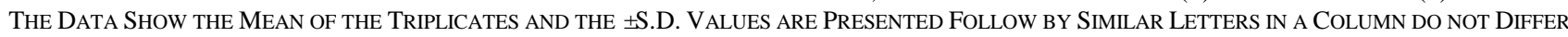
SIGNIFICANTLY AT P $<0.05$.

\begin{tabular}{|c|c|c|c|c|c|c|c|c|}
\hline \multirow[b]{2}{*}{ MJ } & \multicolumn{4}{|c|}{1 week cultured period } & \multicolumn{4}{|c|}{2 week cultured period } \\
\hline & $\begin{array}{l}\text { Growth } \\
\text { (g DW) }\end{array}$ & $\begin{array}{l}\text { Root extract } \\
(\mathrm{mg} / \mathrm{g} \text { DW) }\end{array}$ & $\begin{array}{c}\text { Medium } \\
\text { extract } \\
\text { (mg/g DW) }\end{array}$ & $\begin{array}{c}\text { Total } \\
(\mathrm{mg} / \mathrm{g} \mathrm{DW})\end{array}$ & $\begin{array}{l}\text { Growth } \\
\text { (g DW) }\end{array}$ & $\begin{array}{l}\text { Root extract } \\
(\mathrm{mg} / \mathrm{g} \text { DW) }\end{array}$ & $\begin{array}{c}\text { Medium } \\
\text { extract } \\
(\mathrm{mg} / \mathrm{g} \mathrm{DW})\end{array}$ & $\begin{array}{c}\text { Total } \\
(\mathrm{mg} / \mathrm{g} \mathrm{DW})\end{array}$ \\
\hline (a) & & & & & & & & \\
\hline Control & $\begin{array}{c}0.152 \pm 0.065 \\
\mathrm{a}\end{array}$ & $0.311 \pm 0.063^{\mathrm{a}}$ & $0.030 \pm 0.014^{\mathrm{a}}$ & $0.341 \pm 0.060^{\mathrm{a}}$ & $0.221 \pm 0.119^{\mathrm{a}}$ & $0.404 \pm 0.084^{\mathrm{a}}$ & $0.002 \pm 0.001^{\mathrm{a}}$ & $0.406 \pm 0.083^{\mathrm{a}}$ \\
\hline $0.1 \mathrm{mM}$ & $\underset{\mathrm{a}}{0.121 \pm 0.065}$ & $0^{\mathrm{c}}$ & $0^{\mathrm{b}}$ & $0^{\mathrm{c}}$ & $0.158 \pm 0.062^{\mathrm{ab}}$ & $0^{\mathrm{b}}$ & $0^{\mathrm{a}}$ & $0^{c}$ \\
\hline $0.3 \mathrm{mM}$ & $\underset{\mathrm{a}}{0.132 \pm 0.079}$ & $0.275 \pm 0.042^{\mathrm{ab}}$ & $0^{\mathrm{b}}$ & $0.275 \pm 0.042^{\mathrm{ab}}$ & $0.146 \pm 0.059^{\mathrm{ab}}$ & $0.324 \pm 0.104^{\mathrm{a}}$ & $0^{\mathrm{a}}$ & $0.324 \pm 0.104^{\mathrm{a}}$ \\
\hline $0.5 \mathrm{mM}$ & $\begin{array}{c}0.099 \pm 0.068 \\
\mathrm{a}\end{array}$ & $0.282 \pm 0.069^{\mathrm{ab}}$ & $0^{\mathrm{b}}$ & $0.282 \pm 0.069^{\mathrm{ab}}$ & $0.115 \pm 0.067^{\mathrm{b}}$ & $0.137 \pm 0.065^{\mathrm{b}}$ & $0^{\mathrm{a}}$ & $0.137 \pm 0.065^{b c}$ \\
\hline
\end{tabular}




\begin{tabular}{|c|c|c|c|c|c|c|c|c|}
\hline $1.0 \mathrm{mM}$ & $\begin{array}{c}0.129 \pm 0.039 \\
\mathrm{a}\end{array}$ & $0.396 \pm 0.043^{\mathrm{a}}$ & $0^{\mathrm{b}}$ & $0.396 \pm 0.043^{\mathrm{a}}$ & $0.118 \pm 0.052^{\mathrm{b}}$ & $0^{\mathrm{b}}$ & $0^{\mathrm{a}}$ & $0^{\mathrm{c}}$ \\
\hline \multicolumn{9}{|l|}{ (b) } \\
\hline Control & $\underset{\mathrm{a}}{0.152 \pm 0.065}$ & $0.759 \pm 0.087^{\mathrm{ab}}$ & $0.451 \pm 0.090^{\mathrm{a}}$ & $1.210 \pm 0.170^{\mathrm{ab}}$ & $0.221 \pm 0.119^{\mathrm{a}}$ & $1.402 \pm 0.136^{\mathrm{ab}}$ & $0.027 \pm 0.008^{\mathrm{a}}$ & $1.429 \pm 0.134^{\mathrm{ab}}$ \\
\hline $0.1 \mathrm{mM}$ & $\underset{\mathrm{a}}{0.121 \pm 0.065}$ & $0.589 \pm 0.136^{\mathrm{ab}}$ & $0.027 \pm 0.003^{\mathrm{b}}$ & $0.615 \pm 0.133^{\mathrm{ab}}$ & $0.158 \pm 0.062^{\mathrm{ab}}$ & $0.495 \pm 0.101^{\mathrm{b}}$ & $0^{\mathrm{a}}$ & $0.495 \pm 0.101^{\mathrm{b}}$ \\
\hline $0.3 \mathrm{mM}$ & $\underset{\mathrm{a}}{0.132 \pm 0.079}$ & $1.662 \pm 0.211^{\mathrm{ab}}$ & $0.014 \pm 0.003^{\mathrm{b}}$ & $1.676 \pm 0.207^{\mathrm{a}}$ & $0.146 \pm 0.059^{\mathrm{ab}}$ & $1.393 \pm 0.189^{\mathrm{ab}}$ & $0^{\mathrm{a}}$ & $1.393 \pm 0.189^{\mathrm{ab}}$ \\
\hline $0.5 \mathrm{mM}$ & $\underset{\mathrm{a}}{0.099 \pm 0.068}$ & $1.380 \pm 0.411^{\mathrm{ab}}$ & $0.018 \pm 0.007^{\mathrm{b}}$ & $1.398 \pm 0.408^{\mathrm{ab}}$ & $0.115 \pm 0.067^{\mathrm{b}}$ & $1.052 \pm 0.272^{\mathrm{ab}}$ & $0^{\mathrm{a}}$ & $1.052 \pm 0.272^{\mathrm{ab}}$ \\
\hline $1.0 \mathrm{mM}$ & $\underset{\mathrm{a}}{0.129 \pm 0.039}$ & $1.702 \pm 0.769^{\mathrm{a}}$ & $0.015 \pm 0.002^{\mathrm{b}}$ & $1.716 \pm 0.767^{\mathrm{a}}$ & $0.118 \pm 0.052^{\mathrm{b}}$ & $1.759 \pm 0.826^{\mathrm{a}}$ & $0^{\mathrm{a}}$ & $1.759 \pm 0.826^{\mathrm{a}}$ \\
\hline
\end{tabular}

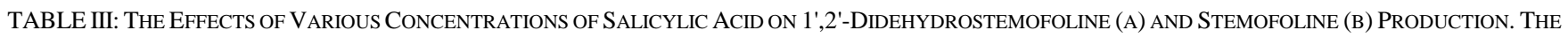

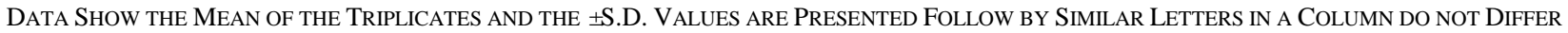
SigNifiCANTLY AT P<0.05.

\begin{tabular}{|c|c|c|c|c|c|c|c|c|}
\hline \multirow[b]{2}{*}{ SA } & \multicolumn{4}{|c|}{1 week cultured period } & \multicolumn{4}{|c|}{2 week cultured period } \\
\hline & $\begin{array}{l}\text { Growth } \\
\text { (g DW) }\end{array}$ & $\begin{array}{l}\text { Root extract } \\
\text { (mg/g DW) }\end{array}$ & $\begin{array}{c}\text { Medium } \\
\text { extract } \\
(\mathrm{mg} / \mathrm{g} \mathrm{DW})\end{array}$ & $\begin{array}{c}\text { Total } \\
\text { (mg/g DW) }\end{array}$ & $\begin{array}{l}\text { Growth } \\
\text { (g DW) }\end{array}$ & $\begin{array}{l}\text { Root extract } \\
\text { (mg/g DW) }\end{array}$ & $\begin{array}{c}\text { Medium } \\
\text { extract } \\
\text { (mg/g DW) }\end{array}$ & $\begin{array}{c}\text { Total } \\
\text { (mg/g DW) }\end{array}$ \\
\hline (a) & & & & & & & & \\
\hline Control & $0.152 \pm 0.065^{\mathrm{ab}}$ & $0.311 \pm 0.063^{b c}$ & $0.030 \pm 0.014^{\mathrm{a}}$ & $0.341 \pm 0.060^{b}$ & $0.221 \pm 0.119^{\mathrm{a}}$ & $0.404 \pm 0.084^{\mathrm{a}}$ & $0.002 \pm 0.001^{\mathrm{a}}$ & $0.406 \pm 0.083^{\mathrm{a}}$ \\
\hline $0.1 \mathrm{mM}$ & $0.172 \pm 0.015^{\mathrm{a}}$ & $0.576 \pm 0.036^{\mathrm{a}}$ & $0^{\mathrm{b}}$ & $0.576 \pm 0.036^{\mathrm{a}}$ & $0.211 \pm 0.017^{\mathrm{a}}$ & $0^{\mathrm{c}}$ & $0^{\mathrm{a}}$ & $0^{\mathrm{c}}$ \\
\hline $0.3 \mathrm{mM}$ & $0.132 \pm 0.012^{\mathrm{bc}}$ & $0.135 \pm 0.033^{\mathrm{ef}}$ & $0^{\mathrm{b}}$ & $0.135 \pm 0.033^{\mathrm{d}}$ & $0.180 \pm 0.009^{\mathrm{bc}}$ & $0.104 \pm 0.027^{\mathrm{bc}}$ & $0^{\mathrm{a}}$ & $0.104 \pm 0.027^{\mathrm{bc}}$ \\
\hline $0.5 \mathrm{mM}$ & $0.157 \pm 0.008^{\mathrm{ab}}$ & $0.347 \pm 0.105^{\mathrm{bc}}$ & $0^{\mathrm{b}}$ & $0.347 \pm 0.105^{\mathrm{b}}$ & $0.191 \pm 0.010^{\mathrm{bc}}$ & $0.210 \pm 0.024^{\mathrm{b}}$ & $0^{\mathrm{a}}$ & $0.210 \pm 0.024^{\mathrm{b}}$ \\
\hline $1.0 \mathrm{mM}$ & $0.117 \pm 0.008^{c}$ & $\underset{\mathrm{e}}{0.194 \pm 0.096^{\mathrm{cd}}}$ & $0^{\mathrm{b}}$ & $0.194 \pm 0.096^{c}$ & $0.139 \pm 0.007^{\mathrm{c}}$ & $0.172 \pm 0.012^{\mathrm{b}}$ & $0^{\mathrm{a}}$ & $0.172 \pm 0.012^{\mathrm{bc}}$ \\
\hline (b) & & & & & & & & \\
\hline Control & $\underset{c}{0.152 \pm 0.065^{a b}}$ & $0.759 \pm 0.087^{\mathrm{a}}$ & $0.451 \pm 0.090^{\mathrm{a}}$ & $1.210 \pm 0.170^{\mathrm{a}}$ & $0.221 \pm 0.119^{\mathrm{a}}$ & $1.402 \pm 0.136^{\mathrm{a}}$ & $0.027 \pm 0.008^{\mathrm{a}}$ & $1.429 \pm 0.134^{\mathrm{a}}$ \\
\hline $0.1 \mathrm{mM}$ & $0.172 \pm 0.015^{\mathrm{a}}$ & $1.884 \pm 0.641^{\mathrm{a}}$ & $0.061 \pm 0.003^{\mathrm{b}}$ & $1.945 \pm 0.640^{\mathrm{a}}$ & $0.211 \pm 0.017^{\mathrm{a}}$ & $1.577 \pm 0.170^{\mathrm{a}}$ & $0.048 \pm 0.006^{\mathrm{a}}$ & $1.625 \pm 0.175^{\mathrm{a}}$ \\
\hline $0.3 \mathrm{mM}$ & $0.132 \pm 0.012^{\mathrm{bc}}$ & $1.194 \pm 0.130^{\mathrm{a}}$ & $0.069 \pm 0.007^{\mathrm{b}}$ & $1.263 \pm 0.136^{\mathrm{a}}$ & $0.180 \pm 0.009^{\mathrm{bc}}$ & $1.188 \pm 0.116^{\mathrm{a}}$ & $0.076 \pm 0.035^{\mathrm{a}}$ & $1.264 \pm 0.098^{\mathrm{a}}$ \\
\hline $0.5 \mathrm{mM}$ & $0.157 \pm 0.008^{\mathrm{ab}}$ & $1.734 \pm 1.274^{\mathrm{a}}$ & $0.041 \pm 0.002^{\mathrm{b}}$ & $1.775 \pm 1.274^{\mathrm{a}}$ & $0.191 \pm 0.010^{\mathrm{bc}}$ & $1.232 \pm 0.217^{\mathrm{a}}$ & $0.022 \pm 0.005^{\mathrm{a}}$ & $1.255 \pm 0.216^{\mathrm{a}}$ \\
\hline $1.0 \mathrm{mM}$ & $0.117 \pm 0.008^{\mathrm{c}}$ & $1.014 \pm 0.239^{\mathrm{a}}$ & $0.108 \pm 0.010^{\mathrm{b}}$ & $1.122 \pm 0.239^{\mathrm{a}}$ & $0.118 \pm 0.052^{\mathrm{b}}$ & $0.869 \pm 0.099^{\mathrm{a}}$ & $0.064 \pm 0.002^{\mathrm{a}}$ & $0.934 \pm 0.101^{\mathrm{a}}$ \\
\hline
\end{tabular}

\section{CONCLUSIONS}

Treatment of Stemona sp. cultures with methyl jasmonate and salicylic acid resulted to enhance Stemona alkaloid production. The highest Stemona alkaloid accumulation was found in the culture using $100 \mu \mathrm{M}$ salicylic acid. This treatment resulted in the production of $1^{\prime}, 2^{\prime}$-didehydrostemofoline and stemofoline in 1.69 fold and 1.61 fold higher amounts than the control, respectively.

\section{ACKNOWLEDGEMENTS}

We gratefully acknowledge support from the Human Resource Development in Science Project (Science Achievement Scholarship of Thailand, SAST), Thailand and the Graduate School, Chiang Mai University, Chiang Mai, Thailand.

\section{REFERENCES}

[1] C. P. Tang, T. Chen, R. Velten, P. Jeschke, U. Ebbinghaus-Kintscher, S. Geibel, and Y. Ye, "Alkaloids from stems and leaves of Stemona japonica and their insecticidal activities," J. Nat. Prod. vol. 71, pp. 112-116, 2007.

[2] B. Brem, C. Seger, T. Pacher, M. Hartl, F. Hadacek, O. Hofer, S. Vajrodaya, and H. Greger, "Antioxidant dehydrotocopherols as a new chemical character of Stemona species", Phytochemistry. vol. 65, pp. 2719-2729, 2004.

[3] L. G. Lin, K. M. Li, C. P. Tang, C. Q. Ke, J. A. Rudd, G. Lin, and Y. Ye, "Antitussive stemoninine alkaloids from the roots of Stemona tuberose", J. Nat. Prod. vol. 71, pp. 1107-1110, 2008.

[4] S. G. Pyne, A. T. Ung, A. Jatisatienr, and P. Mungkornasawakul, "The pyrido[1,2-a]azepine Stemona alkaloids," Maejo Int. J. Sci. Technol. vol. 01, pp. 157-165, 2007.

[5] T. Sastraruji, A. Jatisatienr, S. G. Pyne, A. T. Ung, W. Lie, and M. C. Williams, "Phytochemical studies on Stemona plants: Isolation of stemofoline alkaloids," J. Nat. Prod. vol. 68, pp. 1763-1767, 2005.

[6] M. C. Baird, S. G. Pyne, A. T. Ung, W. Lie, T. Sastraruji, A. Jatisatienr, C. Jatisatienr, S. Dheeranupattana, J. Lowlam, and S. Boonchalermkit, "Semisynthesis and biological activity of stemofoline alkaloids", $J$. Nat. Prod. vol. 72, pp. 679-684, 2009.

[7] T. Sastraruji, S. Chaiyong, A. Jatisatienr, S. G. Pyne, A. T. Ung, and W. Lie, "Phytochemical studies on Stemona aphylla: Isolation of a new stemofoline alkaloid and six new stemofurans", J. Nat. Prod. vol. 74, pp. 60-64, 2010.

[8] W. Chanmahasathien, C. Ampasavate, H. Greger, and P. Limtrakul, "Stemona alkaloids, from traditional Thai medicine, increase chemosensitivity via P-glycoprotein-mediated multidrug resistance," Phytomedicine. vol. 18, pp. 199-204, 2010. 
[9] J. Zhao, L. C. Davis, and R. Verpoorte, "Elicitor signal transduction leading to production of plant secondary metabolites," Biotechnology advances. vol. 23, pp. 283-333, 2005.

[10] P. J. Weathers, M. J. Towler, and J. Xu, "Bench to batch: advances in plant cell culture for producing useful products," Appl. Microbiol. Biotechnol. vol. 85, pp. 1339-1351, 2010.

[11] N. Mirjalili and J. C. Linden, "Methyl jasmonate induced production of taxol in suspension cultures of Taxus cuspidata: ethylene interaction and induction models," Biotechnol. Prog. vol. 12, pp. 110-118, 1996.

[12] T. Murashige and F. Skoog, "A revised medium for rapid growth and bio assays with tobacco tissue cultures," Physiol. Plant. vol. 15, pp. 473-497, 1962.

[13] N. Chaichana, S. Dheeranupattana, A. Jatisatienr, and S. Wangkarn, "Micro-propagation and 1',2'-didehydrostemofoline production from Stemona sp. ," Asian J. Plant Sci. vol. 10, pp. 338-341, 2011.

[14] C. Wasternack, "Jasmonates: an update on biosynthesis, signal transduction and action in plant stress response, growth and development," Annals of Botany. vol. 100, pp. 681-697, 2007.

[15] S. M. Kang, H. Y. Jung, Y. M. Kang, D. J. Yun, J. D. Bahk, J. Yang, and M. S. Choi, "Effects of methyl jasmonate and salicylic acid on the production of tropane alkaloids and the expression of PMT and H6H in adventitious root cultures of Scopolia parviflora," Plant Sci. vol. 166 , pp. 745-751, 2004.

[16] F. Deng, "Effects of glyphosate, chlorsulfuron, and methyl jasmonate on growth and alkaloid biosynthesis of jimsonweed (Datura stramonium L.) ," Pestic. Biochem. Physiol. vol. 82, pp. 16-26, 2005.

[17] L. Van der Fits, H. Zhang, F. L. H. Menke, M. Deneka, and J. Memelink, "A Catharanthus roseus BPF-1 homologue interacts with an elicitor-responsive region of the secondary metabolite biosynthetic gene Str and is induced by elicitor via a JA-independent signal transduction pathway," Plant Mol. Biol vol. 44, pp. 675-685, 2000.

[18] E. Ruiz-May, R. M. Galaz-Avalos, and V. M. Loyola-Vargas, "Differential secretion and accumulation of terpene indole alkaloids in hairy toots of Catharanthus roseus treated with methyl jasmonate," Mol. Biotechnol. vol. 41, pp. 278-285, 2009.

[19] H. Y. Cho, S. Y. Son, H. S. Rhee, S. Y. Yoon, C. W. Lee-Parsons, and J. M. Park, "Synergistic effects of sequential treatment with methyl jasmonate, salicylic acid and yeast extract on benzophenanthridine alkaloid accumulation and protein expression in Eschscholtzia californica suspension cultures," J. Biotech. vol. 135, pp. 117-122, 2008.

[20] N. Jaber-Vazdekis, M. L. Barres, A.G. Ravelo, R. Zarate, "Effects of elicitors on tropane alkaloids and gene expression in Atropa baetica transgenic hairy roots", J. Nat. Prod. 71, 2026-2031, 2008.

[21] D.F. Klessig and J. Malamy, "The salicylic acid signal in plants," Plant Mol. Biol. vol. 26, pp. 1439-1458, 1994.

[22] G. J. Li, S. C. Wang, K. Xia, and X. Zhou, "Effect of yeast elicitor and salicylic acid on the fluctuation of phytohormone contents in Ti-transformed Salvia miltiorrhiza cell cultures," Plant Growth Regulation. vol. 39, pp. 27-32, 2003.

[23] V. P. Bulgakov, G. K. Tchernoded, N. P. Mischenko, M. V. Khodakovskaya, V. P. Glazunov, S. V. Radchenko, E. V. Zvereva, S. A. Fedoreyev, and Y. N. Zhuravlev, "Effect of salicylic acid, methyl jasmonate, ethephon and cantharidin on anthraquinone production by Rubia cordifolia callus cultures transformed with the rolB and rolC genes", J. Biotech. vol. 97, pp. 213-221, 2002.

[24] B. Huang, S. L. Hong, Q. Jin, S. H. Zhang, Y. P. Cai, and Y. Lin, "Effects of SNP, PA and SA on cell growth and physiological activities of suspension-cultured protocorn-like bodies of Dendrobium huoshanense C. ," Plant Physiology Communications. vol. 46, pp. 423-426, 2010.

[25] K. Lee, H. Hirano, T. Yamakawa, T. Kodama, Y. Igarashi, and K. Shimomura, "Responses of transformed root culture of Atropa belladonna to salicylic acid stress," J. Biosci. Bioeng. vol. 91, pp. 586-589, 2001.

[26] S. I. Pitta-Alvarez, T. C. Spollansky, and A. M. Giulietti, "The influence of different biotic and abiotic elicitors on the production and profile of tropane alkaloids in hairy root cultures of Brugmansia candida," Enzyme Microb. Technol. vol. 26, pp. 252-258, 2000.

[27] K. Chotikadachanarong, S. Dheeranupattana, A. Jatisatienr, S. Wangkarn, P. Mungkornasawakul, S. G. Pyne, A. T. Ung, and T. Sastraruji, "Influence of salicylic acid on alkaloid production by root cultures of Stemona curtisii Hook. F.," Curr. Res. J. Biol. Sci. vol. 3 , pp. 322-325, 2011.

[28] J. Durner, J. Shah, and D. F. Klessig, "Salicylic acid and disease resistance in plant", Trends Plant Sci. vol. 2, pp. 1360-1385, 1997. 